\title{
STRESS PLACEMENT AND UNSTRESSED VOWEL PRODUCTION IN ENGLISH NEUTRAL SUFFIXES BY BRAZILIAN LEARNERS ${ }^{1}$
}

\author{
Roberto Rodrigues Bueno \\ (Universidade Estadual da Bahia) \\ Rosane Silveira \\ (Universidade Federal de Santa Catarina/CNPq) \\ Alison Roberto Gonçalves \\ (Universidade Federal de Santa Catarina) \\ Hanna Kivistö-de Souza \\ (Universidade Federal de Santa Catarina)
}

\section{ABSTRACT}

This paper examined the production of unstressed vowels by Brazilian Portuguese (BP) learners of English. More specifically, the aim was to examine the acoustic characteristics of the interlanguage unstressed vowels and to determine whether the language learners' stress assignment in cognate words was targetlike or not. The participants were 20 L1 BP learners of English and two native English speakers who provided the baseline data. Participants read lists of sentences including polysyllabic cognate words with the neutral suffixes "-able" and "-al” (e.g. 'respectable', 'radical'). Participants' productions were acoustically and auditorily analysed and the F1, F2 and duration values measured. The results showed that the L1 BP participants produced a reduced vowel /a/ with similar acoustic characteristics to the L1 English speakers, differentiating it from $/ \Lambda /$ in terms of vowel quality and duration. Despite being able to distinguish between the unstressed and the stressed central vowels, the correct assignment of stress in polysyllabic cognates was challenging for the L1 BP informants. A possible explanation for the non-target-like stress assignment is negative transfer from the L1, in which one of the target suffixes, "-al" (e.g. 'tropical'), attracts stress, contrary to the L2.

KEYWORDS: L2 speech learning; vowel reduction; suprasegmentals. 


\section{Preliminary remarks}

Examining the acquisition of suprasegmentals in the L2 field is still an important endeavour for researchers. Scientific evidence in the area indicates that the acquisition of suprasegmentals has not yet been fully covered, even though they are an important factor for listeners' judgments of L2 speech (TROFIMOVICH \& BAKER, 2006). In this vein, lack of reduction of unstressed vowels is one aspect that is easily noticed in the pronunciation of nonnative English (FLEGE \& BOHN, 1989), resulting in non-native-like rhythm (MUNRO \& DERWING, 1998).

Native-like rhythm may be dependent onto two factors, namely, intonation and stress patterns (FLEGE, 1984; FLEGE \& BOHN, 1989). Giegerich (1992) states that reduced vowels occur only in unstressed syllables, and in monosyllabic grammatical words (e.g., articles and prepositions), the reduction seems to be less predictable than in polysyllabic words. Stressed syllables are believed to be more perceptually prominent when compared to unstressed syllables in four different features: (1) loudness, (2) length (duration), (3) pitch, and (4) vowel quality (formant frequencies) (ROACH, 2000). Roach (2000) explains that some of the four features might be more relevant than others when perceiving/producing unstressed vowels. These features therefore play a role in English vowel reduction. For instance, vowels tend to be shorter, present lower intensity and different quality in weak syllables, whereas in strong ones, they are perceived as relatively longer, having higher intensity and bearing full vowel quality (HILLENBRAND et al., 1995).

In general lines, the bulk of the present study consists of observing how learners stress English polysyllabic words with suffixes while also describing acoustically how this group of learners produced the vowel present in these suffixes. The next section compares stress placement in English and Brazilian Portuguese considering the possible influence of stress patterns stemming from the L1 on the L2.

\section{Stress placement in English and Portuguese}

This section compares stress placement in English and Brazilian Portuguese, with emphasis on the latter, as this might influence the stress placement patterns of English spoken by Brazilians. Regarding English, a strong syllable differs from a weak syllable by having "a rhyme which either has a syllable peak which is a long vowel or diphthong, or a vowel 
followed by a coda (that is, one or more consonants)" (ROACH, 2000, p. 98). Thus, examples of strong syllables in English are 'sea' [si] and 'bet' [bet]. In contrast, a weak syllable has in its peak a short vowel such as [I] or [ə] and it is followed by a coda if the peak is a short vowel (e.g., the last syllables in 'open' ['ou.pən] and 'bit' [bit]).

In Brazilian Portuguese (BP), the stress in a considerable number of words falls on the second syllable from the end of the word (penultimate). However, stress placement in Portuguese can be fairly complex ${ }^{2}$. For instance, noun and verb systems have particularities as stated in Matheus and d'Andrade (2002), who discuss the European Portuguese (EP) system, but whose observations also apply to BP. As the authors explain, verbs are like nouns as they may be phonetically stressed in any of the last three syllables, such as, for the present indicative fala ('you speak') ['fale] and for imperative fale ('speak') ['fali]. The phonological stress normally falls on the penult syllable and, as the authors state, verb stress is commonly attracted by heavy syllables ending in final consonants and final diphthongs (e.g., falei 'I spoke' [fa'ler], 'falar' (to speak) [fa'lah].

Camara Jr. (1986) highlighted that the unstressed vowel sounds are commonly described in relation to the stressed vowels because the latter can have their distinctive traits easily observed and categorized. In this direction, the author divided the BP unstressed vowels in three categories, namely: (1) pre-stressed vowels; (2) post-stressed vowels (non-final position); and (3) unstressed vowels in final position (in open or closed syllables).

Similar to Câmara Jr.'s description for the unstressed vowels in different positions, Mateus and d'Andrade (2002) pointed out that the most remarkable distinction between EP and BP lies in the unstressed vowel system. This distinction is due to the fact that the BP vowels tend to bear their full vowel characteristics in both stressed and unstressed positions and the authors stated that "vowel quality is significantly more independent from word-stress in BP than in EP" (MATEUS \& D'ANDRADE, 2002, p.17).

In the present study, the focus is on the production of vowels that are part of suffixes that appear in post-stressed position in English words. For the post-stressed position, the BP vowel system presents a type of reduction for the mid, back vowel [o], which is commonly pronounced as a high, round [u] (pérola 'pearl' ['perule], and for the mid, front vowel [e] (número 'number' ['numiro]), which can be pronounced as [i]. When 
it comes to unstressed vowels in word-final position, BP's pronunciation for $\left.\langle\mathrm{e}\rangle,<_{0}\right\rangle$ and $\langle\mathrm{a}\rangle$ are reduced to $[\mathrm{I}],[\mathrm{U}]$ and $[\mathrm{e}]$ (Cristófaro-Silva, 2002). This description of part of the BP vowel system is relevant for vowel reduction in English when produced by Brazilian learners because reduced vowels in the BP system in pre-tonic position or in syllable onset tend to lack. This fact might account for the difficulties Brazilians are likely to face to produce English reduced vowels, in particular the schwa vowel when it is part of an unstressed suffix.

\section{Stress placement in suffixed words by Brazilian learners of English}

Due to its crosslinguistic scope, a relevant study to this investigation was conducted by Brawerman-Albini (2007), who examined stress placement in suffixed words by aiming to identify whether stress patterns of Portuguese play an important role in stress placement in English words. More specifically, the study focused on the analysis of non-targetlike stress placement on suffixed English words produced by 20 advanced Brazilian learners of English who had never been to an English speaking country.

A list of suffixed words encompassing three English stress patterns was used to collect data. These were the following: words with stressed syllable on the fourth syllable from the end (e.g.;ar.chi.tec.ture, me.mo. ra.ble, for.tu.na.tely), words with stress on the third syllable from the end (e.g.; e.ter.ni.ty, phe.no.me.nal) and words with stress on the second syllable from the end (e.g.; e.du.ca.tion, ve.ge.ta.rian).

The results showed that the words taking stress on the fourth syllable from the last were extremely difficult. At the sentence level, the informants assigned wrong stress in $72.8 \%$ of the words, while words in isolation were inaccurately stressed $76 \%$ of the time. As for the words receiving stress on the second or third syllable from the last, the informants performed much better, only showing inaccurate stress placement in around $11 \%$ of the time. Findings from the study suggest that inaccurate stress placement produced by the informants appeared to be due to the lack of use of metric principles from the target language, thus rendering much variability in the assignment of stress to these words (BRAWERMAN-ALBINI, 2007, p. 06).

Hence, the present study aims at exploring whether the same phenomena encountered by Brawerman-Albini (2007) occur with learners 
of the language at an intermediate proficiency level when producing words containing the unstressed suffixes '-able', and '-al'. The study observers how such words are stressed and whether the vowels in these suffixes are reduced by the BP speakers of English.

Both suffixes have correlates in BP (e.g., amável "lovely", and normal "normal"), which makes it possible for the corpora to encompass cognate words (e.g., le.xi.cal in EN, and le.xi.cal in BP ), thus allowing for the observation of whether the speakers' L1 induces the process of stress placement over the L2. Moreover, the target suffixes in English do not receive the main stress, but in the informants' L1, one of them, -al, is stressed (lexical [lekisi'kaw]).

Therefore, to achieve the goal of observing stress placement by BP speakers producing suffixed words with '-able' and '-al', the following research questions were posed:

RQ1: How do Brazilian informants produce the English midcentral vowels embedded in suffixes attached to the English polysyllabic cognate words?

RQ2: Do BP informants correctly stress polysyllabic words with neutral suffixes?

\section{Method}

Two production tests were administered to Brazilian learners of English and the vowels' F1, F2 and durational values were compared to those of two American English speakers who provided baseline data. Acoustic and auditory analyses were conducted in order to locate the target syllables and to measure the duration and the quality (first and second formant values) of the target schwa vowel present in the beginning of '-able' and the vowel of the '-al' suffixes. Details about the informants, the tests and the procedure follow in the next sections.

\section{Informants}

A group of 20 female Brazilian speakers of English participated in the study. All of them were from the state of Bahia and were studying at the English Undergraduate Program of Universidade Estadual da Bahia - Jacobina ${ }^{3}$. Informants' ages ranged from 18 to 38 (M: 22.9 years; SD: 4.73). The informants had been studying English from less than a year (six months) to 14 years ( $M: 6.1$ years, SD: 4.2). They had been students at the undergraduate English program from six months to 48 months (M: 23.5; $S D$ : 
11.86). Informants' proficiency level was measured with an online version of the Oxford Placement Test ((http://www.oxfordenglishtesting.com).

For the English baseline data, two female Americans, both 19 years old, one from Kingsport, Tennessee and the other from Detroit, Michigan volunteered to participate as informants. They reported having some knowledge of Spanish, but almost none of Portuguese. At the time of the data collection, they had been in Brazil for three months as part of a university exchange program.

The informants were given a consent form, which they read and signed before the data collection began. This study is in accordance with Resolução 466/12 and it was reviewed and approved by UFSC research Ethics committee, besides being officially consented to by the Department where data collection took place at Universidade do Estado da Bahia (UNEB).

\section{Instruments}

Two production tests were designed. Test A was developed in order to obtain base-line data (quality and duration) of the informants' production of the English /ə/. Test B was designed to examine the informants' production of the / / / and their stress assignment in the target context (suffixes) in order to answer RQ 1 and 2.

The first instrument (Test A, see Appendix) was designed as a preliminary tool to verify whether the participants produced the English mid-central unstressed vowel $(/ / /)$ and the mid-back stressed vowel $(/ \Lambda /)$ distinctly from each other. In order to examine the vowel production, both Brazilian and American speakers of English read 12 sentences which contained the mid-central vowel / / / in the unstressed final syllable of nine words (such as "Africa" and "samba") and the stressed mid back unrounded vowel $/ \Lambda /$ in stressed syllable of nine words (such as "cut" and "love"). Each sentence contained one to three target words, totalling 18. The production of the unstressed/a/ was expected to have lower F1 values and higher $\mathrm{F} 2$ values and to be shorter in terms of duration when compared to the stressed English mid back unrounded vowel / $\Lambda$ (HILLENBRAND et al., 1995).

For the stressed vowel, all tested words displayed onset and coda. Concerning their orthography, they were either spelt with an $<_{0}>$ (six words) or $<\mathrm{u}>$ (three words). For the unstressed mid-central vowel /ə/, we did not attempt to control the position and the spelling, once they 
were all spelt with $<\mathrm{a}>$ and there were seven occurrences of the vowel occupying the final syllable with no coda as in "Africa", and in two tokens, the unstressed vowel was in the first syllable as in "apart". Despite the fact that the words carrying the unstressed vowel were not controlled, we analysed the target words' duration and vowel quality in terms of F1 and F2 in order to check whether the unstressed and the stressed vowels were produced with different acoustic features. This analysis also provided data from the unstressed mid-central vowel to compare with the unstressed vowels present in the target suffixes in the production Test B.

Production Test B was developed to investigate the assignment of lexical stress and the production of English mid-central vowels embedded in two types of neutral suffixes present in polysyllabic words. For such objectives, the American and Brazilian speakers of English were required to read a list of 16 polysyllabic words holding /o/ in their neutral/ unstressed suffixes. The English words included in Test B had either three (e.g. "tropical") or four syllables (e.g. "adaptable"). The three-syllable words carried the suffix " $-\underline{a} l$ " and the four-syllable words carried the suffix "- $\underline{a} b l e "$. We followed Roach (2000) in choosing these suffixes, which the author calls neutral suffixes because they do not affect the stress of the words to which they are added. For instance, the word "believe" and "believable" are both stressed on the second syllable from the left. For the

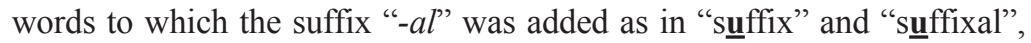
the stressed syllables fall on the first syllable from the left. In this study, the initial vowel of the suffixes, produced as /ə/in some standard varieties of English was analysed.

Literature reports on some variation regarding the pronunciation of the target suffixes. For Roach (2005), there is no vowel /a/ preceding the $/ 1 /$ in the suffixes '-able' and '-al', and the /1/ is syllabic, as in detectable /dı'tcktəbl, /and digital /'didzitł/. However, Giegerich (1995) states that, in addition to this pronunciation, there is the variant with a schwa: detectable /dı'tcktəbə1/ and digital / ' didzitəl/. In the present study, we assume the second kind of transcription proposed by Giegerich (1995), which we expect to be more likely to reflect the pronunciation of Brazilian learners of English as well. Besides, for the '-able' suffix, our interest is in measuring the first schwa sound, which precedes the bilabial stop, while for '-al' we will focus on the schwa that precedes $/ 1 /$.

All the words in the Production Test B were cognates in BP in order to examine the influence of the L1 on the L2. Thus, our goal was to 
investigate to what extend the stress patterns that the Brazilian informants used in the target words resembled those of the dictionarised target forms or resembled the similar word form present in BP, thus showing strong influence from their L1. We also attempted to examine whether L1 transfer could explain the vowel quality of the vowels in the English suffixes. It is noteworthy to observe that, for the Portuguese cognates, the stress for the words ending with the "-vel" suffix (e.g., adaptável 'adaptable') falls on the second syllable from the end (paroxytone), whereas for the suffix, "-al" (e.g., tropical, 'tropical'), the stress falls on the last syllable (oxytone).

Curiously, suffixes in Portuguese are commonly described by authors such as Cristófaro-Silva (2006) as having a tendency to attract or interfere in the word stress (e.g., real, 'real') [he'aw], realmente, 'really' [heaw'mẽtI] ${ }^{4}$. However, one of the suffixes chosen in this study, "-vel", does not have this feature of attracting or changing stress, thus behaving similarly to its English counterpart "-able". For example, "-vel" is added to verbs ending in "-ar" in the infinitive forms, thus forming adjectives (e.g., coletar 'collect' (verb, infinitive [kole'tah]) becomes coletável 'collectable' (adjective, [kole'tavew]). As for "-al", the suffix is added to nouns ending in -o to form adjectives (e.g., léxico 'lexicon' [1'ckisikv] (adjective, lexical, 'lexical' [lekisi'kaw])), and this suffix carries stress, contrary to its English equivalent "-al". Table 1 below presents the stimuli used in Test B.

Table 1 - Groups of English words ending with unstressed suffixes

\begin{tabular}{|l|l|}
\hline Words ending in -able & Words ending in-al \\
\hline Respectable & Tropical \\
\hline Detectable & Suffixal \\
\hline Contestable & Radical \\
\hline Collectable & Medical \\
\hline Adoptable & Lexical \\
\hline Adjustable & Digital \\
\hline Adaptable & Criminal \\
\hline Acceptable & Affixal \\
\hline
\end{tabular}




\section{Proficiency Test}

An online placement test developed by Oxford University Press was given to measure the BP participants' English proficiency levels and to screen for intermediate level students to participate in the study. Forty-four prospective informants took the test and 20 finished within the allowed time limit $(80 \mathrm{~min})$. They were placed at the intermediate level $(\mathrm{B} 1=5 ; \mathrm{B} 2=15)$, thus being invited to participate in the data collection. This proficiency level was deemed adequate for the present study purposes, since these learners were not expected to have difficulties performing the tasks and, at the same time, would display pronunciation patterns that could reveal the role of the L1 phonology in L2 production.

\section{Procedures for Data Collection}

The tests were administered in the following order: proficiency test, Production Test A and Production Test B. The participants were recorded individually in the sound-proof cabin of the language lab at the university in Jacobina (Bahia).They also received instructions in English about their reading speech rate before starting the digital recordings, and they were given a short interval from one production test to another to prevent them from feeling tired. Words and sentences were recorded at a sampling frequency rate of $22050 \mathrm{~Hz}$ by using the sound recorder tool Praat (version 5.3.57), and a dynamic, multilateral SM81LC Shure microphone. The computer used for recording and storing the digital files was a Dell Inspiron Ultrabook.

\section{Data analysis for Production Tests $A$ and $B$}

For both production tests, A and B, the F1 and F2 values and the duration for the schwa produced by the Brazilian and American informants were acoustically analysed. In addition, the position of the lexical stress was analysed for Test B. The first step was to map both stressed and unstressed vowels produced by the BP and English informants. For this step, we relied on the authors' auditory analysis to determine where the stressed syllable was, as well as on acoustic features such as duration, amplitude, pitch and intensity of the formants.

Figure 1 shows a generated acoustic signal of the word "detectable" produced by an American female who participated as baseline in this study. This informant's productions were analysed in terms of duration (in milliseconds) and F1 and F2 values (in Hertz) to be later compared with the Brazilian learners. 
Figure 1 -The labelling of the polysyllabic word "detectable" produced by a female native English speaker of American English.

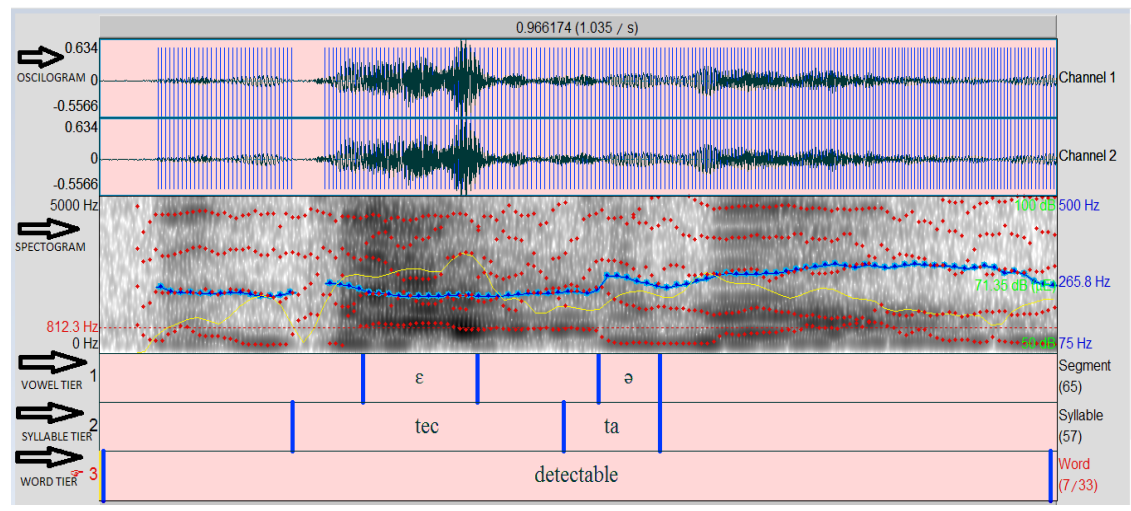

For labelling the acoustic speech signal, the software Praat (version 5.3.57) was used. Both F1 and F2 values are obtained from the vowel temporal midpoint, where the periodic vocalic pulses are steadier when compared to the first (vowel onset) and third point (vowel ending) temporal points (BAPTISTA, 2006). By measuring the vowel midpoints, we attempted to reduce the influence of adjacent sounds (coarticulation) and of transitions.

To have the informants' vowels in the production tests plotted, all the rough acoustic vowel data were carefully selected. This selection consisted of establishing the cut offs values for the F1 and F2, following a suggestion provided by Gonçalves (2014). For instance, only F1 values which ranged from under 400 to over 1000 were used. For the F2 values, the cut-off ranged from under 1000 to over 2000. These cut-offs were obtained by inspecting the literature (HILLENBRAND et al., 1995, RAUBER, 2006), which suggested no mid-central and low vowels lower than 400 , or higher than 1000 . Thus, only F1 and F2 values that resembled a vowel were used for the plotting. Other values were excluded from the data spreadsheets. Since our data were non-normalized, we followed Gonçalves' (2014) procedures for building vowel graphs. They were conducted through the script "Plotar vogais", written by Bion (2006). For plotting for dispersion (vowel loci), "Plot from table", also written by Bion (2006), was used in order to look at possible vowel overlaps by informants in the production tests. 


\section{Results and discussion}

This study was conducted to examine how Brazilian learners of English produce words with the neutral suffixes '-able' and '-al', focusing on the quality of the schwa vowels and stress placement of suffixed words. The first step was to examine baseline data from American and Brazilian informants from Test A, which enabled us to compare the acoustic differences between the English vowel in stressed position $[\Lambda]$ and the unstressed vowel [ə]. These results were essential to carry out the second step, which consisted of analysing relative duration and vowel quality data (F1 and F2) for the Test B words. The analysis of Test A data helped us to have a better understanding of how the schwa was produced in unstressed position of non-suffixed words such as 'again' or 'Africa', and enabled the comparison of the acoustic values with those obtained for the schwa vowel from the suffixed words (Test B). Finally, we looked into the stress placement results for Test B to check whether the BP informants had any difficulties in assigning stress to suffixed words.

\subsection{Vowel Quality Results}

The data from Test A were examined to have baseline data about the production of the schwa sound for Brazilian learners of English in non-suffixed-words. Table 2 shows the descriptive statistics for the two English vowels $[\Lambda]$ and [ə] when produced by the Brazilian and American speakers of English. For the BP group, the mean F1 in stressed vowels was 652 , which was very close to the F1 in the unstressed vowel, whose mean was 686. Similar results for the F2 means for both vowels were found. The F2 mean for the stressed vowel was 1389 and the mean for the unstressed vowel was 1559 . 
Table 2 -Descriptive statistics for the production of the English stressed vowel $[\Lambda]$ and the English unstressed vowel [ə] by the Brazilian and the American informants

\begin{tabular}{|c|c|c|c|c|c|}
\hline & \multicolumn{3}{|c|}{ Brazilian Informants $(\mathrm{n}=14)$} & \multicolumn{2}{|c|}{$\begin{array}{l}\text { American Informants } \\
(n=2)\end{array}$} \\
\hline & Mean & $\mathrm{SD}$ & Min-Max & Mean & Min-Max \\
\hline $\mathrm{F} 1[\Lambda]$ & 652 & 108 & $452-923$ & 765 & $640-991$ \\
\hline $\mathrm{F} 2[\Lambda]$ & 1389 & 265 & 773. -1952 & 1537 & $1264-1708$ \\
\hline Duration of $[\Lambda]$ & 35 & 10 & $9-62$ & 35 & $15-54$ \\
\hline $\mathrm{F} 1[ə]$ & 686 & 134 & $451-950$ & 600 & $483-687$ \\
\hline F2 [ə] & 1559 & 234 & $789-2130$ & 1624 & $1180-1859$ \\
\hline Duration of [ə] & 22 & 7 & $8-47$ & 21 & $7-44$ \\
\hline
\end{tabular}

It is important to note that there was a large variation between the minimum and maximum values for F1 and F2 for both vowels produced by the BP group. It is worth observing how low the minimum F2 values for $[\Lambda]$ and [ə] were, and how high the F1 and F2 values were for [ə], when compared to the minimum and maximum values produced by the American informants. These values are a clear indication that the BP participants were producing non-target-like vowels. More specifically, the low F2 value for $[\Lambda]$ and $[ə]$ indicate that some participants might have produced the target sounds as the BP high back vowels $[\mathrm{u}]$ (e.g., 'hut' $[\mathrm{u}]$ ) or [o]('love' [o]; cf. formant values for these vowels reported in Pereira, 2001). Furthermore, the high F1 value for [ə] suggests that, sometimes, it was produced similar to the BP central vowel [a] (e.g., 'yoga' ([a]) (see PEREIRA, 2001 and SEARA, 2001)

A possible explanation for these results is that these learners might have not yet acquired stable categories for the investigated vowels by the time data collection took place. Following Flege (1995), we assume that non-target-like vowel production is due to inexistent or unstable L2 categories. In other words, whereas native speakers' vowel productions are relatively stable and present relatively little variation, foreign language learners who have yet to acquire the stable L2 categories tend to produce L2 vowels that overlap more. These learning difficulties are likely to arise due to the different acoustic environment of such vowels, as well as 
differences in syllable idiosyncrasies (open and close), and the different orthographic symbols used to represent these vowels (ex., love, but).

Concerning the duration for the stressed vowel, the mean was $35 \mathrm{~ms}$ for both BP and American informants, whereas for the unstressed one, the duration was $22 \mathrm{~ms}$ for the BP group and $21 \mathrm{~ms}$ for the American informants. This confirmed that unstressed vowels are relatively shorter than their stressed counterparts (LADEFOGED, 2010; WATKINS, 2001; WATKINS, BRAWERMAN-ALBINI, BERTOCHI, 2010), and the BP informants produced the two vowels with similar durations as the native English speakers.

Three Wilcoxon tests were conducted to compare the F1 and F2, and duration of the two vowels produced by the Brazilian learners in Test A. The results showed that the stressed and unstressed vowels differed significantly in terms of vowel quality (F1: $p: .034 \mathrm{Z}:-2,119 ; \mathrm{F} 2: p$ : $.000 \mathrm{Z:}:-4,788)$ and duration (p .000 Z: -8,912). This shows that the BP informants produced two distinct vowels in terms of quality and duration, despite their dispersion and their mean values for F1 and F2 being close as shown in Table 2. Nevertheless, we should keep in mind that even though these differences were statistically significant, they might not be auditorily perceivable for native English speakers. In other words, unless a perception test with these vowel productions is carried out, it cannot be confirmed that the BP informants in fact produced two auditorily distinct L2 vowels.

Having discussed the results for Test A and obtained information about the acoustic features of the unstressed schwa in the production of the Brazilian leaners, we turn now to the analysis of Test B data, so as to discuss how the same groups of learners produced the English unstressed vowel in polysyllabic words containing the two neutral suffixes.

Table 3 presents the descriptive statistics for the production of the English vowel [ə] in the target suffixes "-al" and "-able". For the Brazilian informants, we can see that the means of F1 and F2 values in the English vowel in "-al" were 636 and $1377 \mathrm{~Hz}$ respectively. For the suffix "-able", the F1 mean was $589 \mathrm{~Hz}$ and F2 was $1587 \mathrm{~Hz}$. The duration of the schwa in the suffix "-al" was $13 \mathrm{~ms}$ and in the suffix "-able" $8 \mathrm{~ms}$. With a first glance, it appears that there is a difference in the production of the schwa in the two suffixes. However, when the minimum and maximum values for F1 and F2 and duration are seen, the range of the values corroborates previous studies, which have found that the unstressed English vowel can 
demonstrate greater differences in terms of F1 and F2 values because of its nature of centrality and the fact that it is in constant contrast to a stressed full-vowel counterpart (Watkins \& Rauber, 2010). Moreover, the difference can be noticed in the duration due to aspects like phonological environment and syllable structure (YAVAS, 2011).

Table 3 -Descriptive statistics for the production of the English: [ə] and $[\Lambda]$ in the unstressed "-al" and "-able" by the Brazilian and American informants

\begin{tabular}{llllll}
\hline & \multicolumn{3}{l}{ Brazilian Informants $(n=14)$} & \multicolumn{2}{c}{ American Informants $(n=2)$} \\
\cline { 2 - 7 } & $\underline{\text { Mean }}$ & $\underline{\text { SD }}$ & $\underline{\underline{\text { Min-Max }}}$ & $\underline{\text { Mean }}$ & $\underline{\text { Min-Max }}$ \\
\hline F1 '-al' & 636 & 128 & $460-899$ & 644 & $456-833$ \\
F2 '-al' & 1377 & 173 & $1109-1804$ & 1781 & $1663-2013$ \\
Duration '-al' & 13 & 3 & $6-22$ & 17 & $9-25$ \\
F1 '-able' & 589 & 104 & $450-861$ & 635 & $443-827$ \\
F2 '-able' & 1587 & 183 & $1109-1987$ & 1692 & $1512-1871$ \\
$\begin{array}{l}\text { Duration } \\
\text { '-able' }\end{array}$ & 8 & 3 & $3-28$ & 10 & $7-13$ \\
\hline
\end{tabular}

Table 3 also displays the data produced by native speakers of English, showing that, for this group, the mean F1 was 644 and F2 was 1781 for the suffix "-al". As for the suffix "-able", the native speakers produced mean F1 values of 635 and F2 values of 1692. We observed that duration was $17 \mathrm{~ms}$ for the suffix "-al" and that a shorter relative duration was displayed for the suffix "-able", 10ms.

Thus, by looking at the values displayed in Table 3 (Test B data) and comparing them to the F1, F2 and duration values of the unstressed vowel of the test A, that for both the Brazilian and American informants (Tables 2 and 3), there was some variation in their production of the unstressed vowel in suffixed and non-suffixed words. Focusing on the results for the BP informants, we can say that the unstressed vowel in non-suffixed words (e.g. "samba") was produced with higher F1- F2 $(686,1559)$ and duration (22ms) values than the unstressed suffixed vowels. Regarding vowel duration, the vowels in the suffix "-able" were much shorter than those in the suffix "-al". Maybe this is due to the fact that the "-able" vowels were followed by a stop consonant and the second one by a liquid sound, which 
made it longer. Besides that, both vowels were shorter than those produced by the American speakers. It is possible that the BP speakers overemphasize the duration in the production of unstressed syllables, but this topic deserves further investigation comparing L1 and L2 production data.

In Figure 2, we can see the productions of the unstressed vowel in the target English suffixes produced by the Brazilian informants. In this figure, it is remarkable how low the vowel in the suffix "-al" - is in comparison to the vowel in the suffix "-able". This difference is likely to be related to the fact that the tokens produced in the first suffix were harder to pronounce and possibly more prone to L1 transfer compared to more common words present in the "-able" suffixes. Besides that, tokens containing the "-al" suffixes resembled most the Portuguese words (e.g. 'adaptable' - adaptável), thus orthography might have triggered L1 prosodic patterns, which included stressing the suffix and producing its vowel as the L1 [a].

Figure 2 -Unstressed vowels produced in the suffixes "able" and "al" by 20 Brazilian informants. The vowels are represented by their respective suffixes: (ab) and (al).

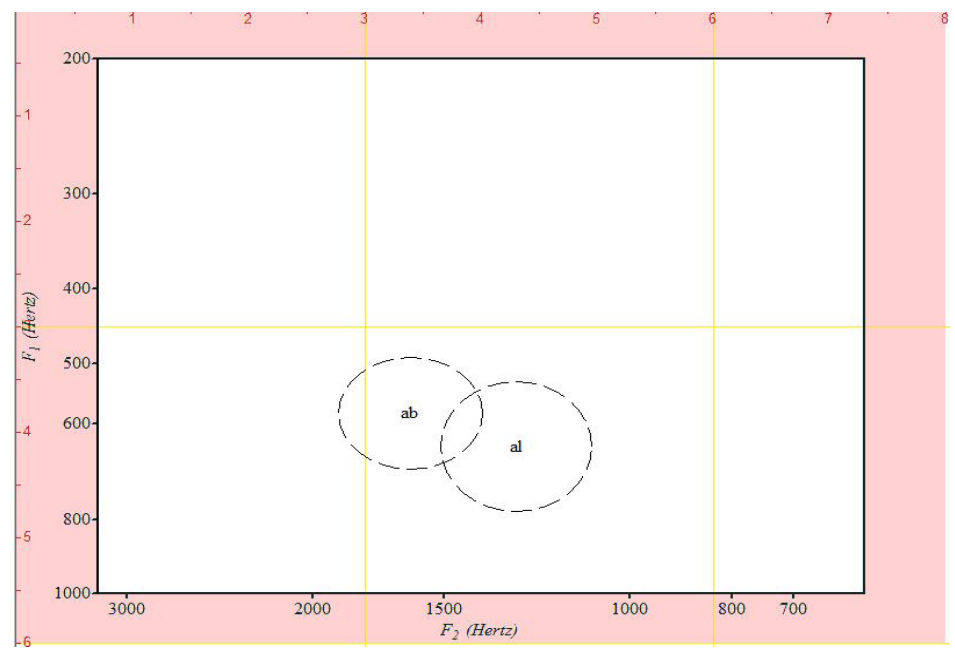

Using the BP informants' data, Wilcoxon tests were run to compare the F1, F2 and duration results for the production of the two unstressed suffixes "-al" and "-able", which revealed that the BP informants produced significantly different values for the three acoustic measures when the two suffixes are compared, as it can be observed in Table 4 below. Even 
though significant differences were observed in all of the three measures for the two suffixes, we cannot confirm with the present data whether these differences occur because of the different phonological environment, the types of words or cognate status. Whether these differences are due to the different phonological environment surrounding the suffixes and to the types of word used for each suffix remain an issue for further studies. The results displayed for the two native speakers of English hint at the important influence of the phonological environment, given that a similar pattern, especially regarding duration, displaying the vowels of the suffix as longer when compared to the BP English learners.

Table 4 - Results of a Wilcoxon test run to check the differences between the production of the English [ə] present in the suffixes "-able" and "-al"

\begin{tabular}{llll}
\hline & F1 unstressed -able & F2 unstressed -able & Duration -able \\
& F1 unstressed -al & F2 unstressed -al & Duration -al \\
Z & -2.967 & -6.104 & -7.686 \\
p. & .003 & .000 & .000 \\
\hline
\end{tabular}

Previously, results were described to show how 20 Brazilian informants produced the vowel present in unstressed suffixes and we discussed whether this production had statistical significance when the different suffixes were compared. The answer was positive, meaning that by the quality and duration values obtained in the production of these vowels, it is possible that the stress patterns of the tested words contributed to these differences. The difference across the two types of suffixes was also noticed and similar to the production of two American informants.

For all tokens containing the suffix '-able' (e.g. 'respectable'), the previous syllable was expected to be stressed. This way, the target sound, which immediately followed the stressed syllable, would be likely to be produced with less loudness, length and lower pitch, as shown in the literature (WATKINS, 2001; YAVAS, 2011). In tokens containing the "-al" suffixes, however, the literature predicts that the stress would never fall in the previous syllable, e.g. ('affixal). Thus, we can infer that the position of the stressed syllable plays an important role in the production of English vowels, especially in terms of duration and vowel quality. 


\subsection{Stress Placement Results}

Research question 2 inquired how Brazilian learners from intermediate proficiency levels, assigned stress to English cognate polysyllabic words (ex. respectable). In order to answer this question, we tallied the number of correct stress placement for each participant. To observe whether stress placement was target-like, an auditory analysis was carried out, followed by a visual analysis done using Praat. This visual analysis, carried out by one of the authors, consisted of the inspection of the pitch line (the blue line), and the inspection of intensity (yellow line) in relation to the vowel quality. This was because intensity is higher whenever a segment is stressed, which is indicated by the pitch line. We observed that whenever the pitch line was misplaced in the production of the word, the vowel had a different quality. For instance, in the word 'respectable', some speakers pronounced the 'a' either as [eI] or [a], resulting in [IIspek'terbəl] and [IIspek'tabəl], respectively. Participants' rates of target-like stress assignment to the unstressed suffixed syllables can be seen in Table 5 below.

Table 5 - Participants' rates of target-like stress placement for suffixed words (Test B)

\begin{tabular}{l|l|l|l}
\hline Participant & $\begin{array}{l}\text { \% of target-like } \\
\text { stress placement }\end{array}$ & Participant & $\begin{array}{l}\% \text { of target-like } \\
\text { stress placement }\end{array}$ \\
\hline BS1 & 100 & BS11 & 75 \\
BS2 & 75 & BS12 & 87,5 \\
BS3 & 68,75 & BS13 & 87,5 \\
BS4 & 81,25 & BS14 & 62,5 \\
BS5 & 75 & BS15 & 100 \\
BS6 & 68,75 & BS16 & 75 \\
BS7 & 81,25 & BS17 & 62,5 \\
BS8 & 87.5 & BS18 & 87,5 \\
BS9 & 93,75 & BS19 & 68,75 \\
BS10 & 81,25 & BS20 & 100 \\
\hline
\end{tabular}

From the 20 participants, only three obtained $100 \%$ of correct responses in the stress placement test, with the lowest percentages around $62 \%$ and $68 \%(M=80.5 \%)$. By considering that this type of neutral suffix 
does not attract stress in English, contrary to BP in which the "-al" suffix carries lexical stress (BISOL, 2010), we speculate that the L1 influenced the L2 stress assignment in this context. In fact, if we examine the results for stress placement per type of suffix, displayed in Table 6, we can see that a few words posed more difficulty than others. While only one "-able" word triggered less than $85 \%$ of correct responses ('adaptable': $65 \%$ ), four words ending in "-al" yielded lower percentages of correct responses, and two of them were extremely difficult to the participants: 'affixal' (35\%) and 'suffixal' (30\%). It is important to notice that the two test items that presented the lowest accuracy scores are lexemes with a very low word frequency. This finding seems to go in line with previous research indicating the effect of word frequency and word familiarity on L2 speech learning as if the speaker does not know the word, an accurate mental representation for that word cannot exist (MORA, 2005) Furthermore, note that the "-al" suffix attracts word stress in BP, and this might account for the rates of incorrect stress assignment in the data. Consequently, we assume that negative L1 transfer played some part in the production of L2 cognate suffixes. These results parallel those of Brawerman-Albini (2007) in that BP learners of English appear to face some difficulties with target-like word-stress assignment, even in more advanced proficiency levels.

Table 6 - Rates of target-like stress placement per word

\begin{tabular}{llll}
\hline '-able'words & \% of target-like stress & '-al' words & $\begin{array}{l}\% \text { of target-like } \\
\text { stress }\end{array}$ \\
\hline Acceptable & 95 & Radical & 100 \\
Respectable & 95 & Tropical & 100 \\
Collectable & 90 & Medical & 95 \\
Adjustable & 90 & Lexical & 90 \\
Detectable & 90 & Digital & 80 \\
Adoptable & 85 & Criminal & 70 \\
Contestable & 85 & Affixal & 35 \\
Adaptable & 65 & Suffixal & 30 \\
\hline
\end{tabular}

Having an intermediate level of proficiency did not compel learners to surpass their difficulties in dealing with L2 suprasegmental cues when 
producing suffixed words. It appears that suprasegmental components of an L2 should be addressed in the L2 syllabus, which should include explicit instruction on this type of knowledge. This is especially justified as previous research indicates that consciousness-raising activities, such as explicit teaching, for instance, are extremely beneficial for L2 speech development (e.g. ALVES; MAGRO, 2011; CEBRIAN; CARLET 2014; COUPER, 2011; RATO, 2013; SAITO; WU, 2014).

\section{Concluding remarks}

The present study examined the production of the English midcentral vowel in neutral suffixes by intermediate BP learners of English. The study aimed at describing the acoustic characteristics of the interlanguage vowel as well as examining whether the L2 learners were able to assign stress correctly in cognate words. Before addressing the production of the unstressed English vowel embedded in the English suffixes, the production of the stressed and unstressed English vowels in Test A was described, which contained non-suffixed English words, in order to check how different the English vowel in stressed position $[\Lambda]$ and the unstressed vowel [ə] were. Vowel quality and duration values were taken into account, as these were the acoustic feature variables chosen to analyse these vowel productions. Statistical analysis demonstrated that these English stressed and unstressed vowels differed in terms of vowel quality and duration values $(p .<.05)$. This distinction seems to be because the acoustic features (duration and F1-F2) produced by BP learners of English were similar to the pattern observed for American informants' values in the present study.

Neutral suffixes, at least the two tested in the present study, posed difficulties to BP learners of intermediate proficiency levels, triggering problems in stress placement, and often stress placement mistakes resulted in the production of vowels that were not similar to a schwa. However, it is important to bear in mind that the small data sample and small set could have influenced this result. Another possible reason for this result was that the English suffixes tested in the present study ("-able", "-al") never carry stress, whereas one of their Portuguese counterparts do (BISOL, 2010). Thus, it was suggested that the L1might have led to negative transfer of L1 stress assignment patterns. Therefore, it was noticed that intermediate level BP learners of English might face difficulties when acquiring some suprasegmental aspects of the L2 speech. As previous 
research (e.g. FLEGE \& BOHN, 1989; PASSARELLA DOS REIS, 2017; TROFIMOVICH \& BAKER, 2006) indicates, non-target-like production of stress is likely to hinder comprehension and result in perceived foreignaccentedness. Therefore, we suggest that future studies address the acquisition of English stress assignment by BP learners more in depth, by employing different task types, stimuli and participants. Similarly, we also call for studies examining the effectiveness of consciousnessraising activities on BP EFL learners' stress acquisition. Only in this manner, will we better comprehend the role L1 stress assignment plays in L2 communication and the type of instruction we could employ to help learners to overcome any communication breakdowns.

\section{A ACENTUAÇÃO TÔNICA E A PRODUÇÃO DA VO- GAL ÁTONA EM SUFIXOS NEUTROS DO INGLÊS POR APRENDIZES BRASILEIROS}

\section{RESUMO}

O presente estudo investigou a produção de vogais átonas por aprendizes brasileiros de inglês. O objetivo principal foi examinar as características dessas vogais entre as duas línguas em contato e determinar se os aprendizes atribuíam acento tônico adequadamente. Os participantes foram 20 alunos brasileiros de inglês e dois falantes nativos que forneceram dados de base. Os participantes leram listas de frases incluindo palavras polissilábicas cognatas com os sufixos neutros "-able" e "-al" (por exemplo, "respectable", "radical"). As produções dos participantes foram analisadas acústica e auditivamente e os valores de F1, F2 e duração das vogais átonas foram medidos. Os resultados mostraram que os participantes brasileiros produziram a vogal/ə/ com características acústicas similares aos falantes nativos de inglês, diferenciando-a de $/ \Lambda / \mathrm{em}$ termos de qualidade e duração da vogal. Apesar de serem capazes de distinguir as vogais centrais átona e tônica, a atribuição correta do acento tônico em cognatos polissilábicos foi desafiadora para os informantes brasileiros. Uma possível explicação para a atribuição 
inconsistente do acento tônico é a influência do português brasileiro, em que um dos sufixos alvo, "-al" (por exemplo, "tropical"), atrai a tonicidade, ao contrário do que tipicamente ocorre no inglês. PALAVRAS-CHAVE: aquisição da fala em L2; redução vocálica, suprassegmentos.

\section{NOTAS}

${ }^{1}$ The study protocol was approved of by UFSC Ethics Research Board under the register 1.232.679, issued on September $17^{\text {th }}, 2015$. The second and third authors would like to thank CNPq for the research grant.

${ }^{2}$ In BP, diacritical signs $\left(',{ }^{\wedge}\right)$ are used to indicate the stressed syllables of certain words.

${ }^{3}$ The option for collecting data in Jacobina was made by one of the authors, for its convenience, as well as for these subjects were learners who had never been scope of any sort of scientist study of this kind before.

${ }^{4}$ Note that the phonetic transcriptions of the vowels present in these Portuguese words were in accordance to the BP Portuguese variety of the informants. In other $\mathrm{BP}$ varieties, the pre-tonic vowels may vary (.e.g., real [he'aw].

\section{REFERENCES}

ALLAN, D. Oxford Placement Test 1.Oxford: Oxford University Press, 2004.

ALVES, U. K.; MAGRO, V. Raising awareness of L2 phonology: Explicit instruction and the acquisition of aspirated $/ \mathrm{p} /$ by Brazilian Portuguese speakers. Letras de Hoje, Porto Alegre, v. 46, n. 3, p. 71-80, July 2011.

BAPTISTA, B. O. Adult phonetic learning of a second language vowel system. In: BAPTISTA, B. O.;WATKINS, M. A. (Eds.). English with a Latin Beat: Studies in Portuguese/Spanish - English Interphonology. Amsterdam: John Benjamins,2006. p. 19-40. 
BISOL, L. (Org.). Introdução a estudos de fonologia do português brasileiro. 5 ed. PortoAlegre: EDIPUCRS, 2010, v.1, 286 p.

BRAWERMAN-ALBINI. A Stress placement in suffixed words by Brazilian students of English. In: NEW SOUNDS 2007 - FIFTH INTERNATIONAL SYMPOSIUM ON THE ACQUISITION OF SECOND LANGUAGE SPEECH, 2007, Florianópolis. Anais... Florianópolis, 2007, p. 1-9.

BRAWERMAN-ALBINI, A. Os efeitos de um treinamento de percepção na Aquisição do padrão acentual pré-proparoxítono da Língua inglesa por estudantes brasileiros. 2012. 339 f. Tese (Doutorado em Letras) - Setor de Ciências Humanas, Letras e Artes, Universidade Federal do Paraná, Curitiba. 2012.

CÂMArA JR., J. M. (1953). Para o estudo da fonêmica Portuguesa. Rio de Janeiro: Organização Simões, 1977. (2. ed., preparada por Raimundo Barbadinho Neto de acordo com instruções deixadas pelo autor. Rio de Janeiro: Padrão,).

CEBRIAN, J.; CARLET, A. Second language learners' identification of target language phonemes: A short-term phonetic training study. Canadian Modern Language Review, Toronto, v. 70, n. 4, p. 474-499, Nov. 2014.

COUPER, G. What makes pronunciation teaching work? Testing for the effect of two variables: socially constructed metalanguage and critical listening. Language Awareness, London, v. 20, n.3, p. 159-182, Oct. 2011.

CRISTÓFARO-SILVA, T. Fonética e Fonologia: Perspectivas complementares.

Estudos da Linguagem, Belo Horizonte, v.3, n. 2, p. 25-40, 2006.

CRISTÓFARO-SILVA, T. Phonological Variation in verbs ending in -EAR and -IAR. Fórum Linguístico, Florianópolis, v. 5, n. 1, p. 13-27, 2008.

FLEGE, J. E. The detection of French accent by American listeners. Journal of the Acoustical Society of America, v. 76, n. 3, p. 692-707, 1984.

FLEGE, J. Second language speech learning, theory, findings and problems. In: STRANGE, W. (Org.). Speech perception and linguistic experience: Issues in cross-language research. Timonium: York Press, 1995. p. 233-277.

FLEGE, J. E.; BOHN, O. S. An Instrumental study of vowel reduction and stress placement in Spanish-accented English. Studies in Second Language Acquisition, v. 11, n. 1, p. 35-62, 1989.

GIEGERICH H. J. English phonology: An introduction. Cambridge: Cambridge University Press, 1992. 333 p.

GONÇALVES, A. R. In search of speech intelligibility: The case of English high front vowels. 2014. 170 f. Dissertação (Mestrado em Letras Inglês e Literatura Correspondente) - Centro de Comunicação e Expressão, Universidade Federal de Santa Catarina, Florianópolis. 2014. 
HILLENBRAND, J.; GETTY, L. A.; CLARK, J. M.; WHEELER, K. Acoustic characteristics of American English vowels. Journal of the Acoustical Society of America, Melville, v. 97, p. 3099-3111, 1995.

LADEFOGED, P. Vowels and Consonants: An Introduction to the Sounds of Languages. Oxford: Blackwell, 2010. 216f.

LARSON-HALL, J. A guide to doing statistics in second language research using SPSS. New York: Routledge, 2010. 423 p.

MATHeUS, M. H.; D'ANDRADE, E. The Phonology of Portuguese (The Phonology of the World's Languages). London: Oxford University Press, 2002. $176 \mathrm{p}$.

MORA, J.C. Lexical knowledge effects on the discrimination of non-native phonemic contrasts in words and non-words by Spanish/Catalan bilingual learners of English. In: ISCA Workshop on Plasticity in Speech Perception, 2005, London. Proceedings of ... London: Dep. of Phonetics and Linguistics, University College London, 2005. p. 43-46.

MUNRO, M. J.; DERWING, T. M. The effects of speaking rate on listener evaluations of native and foreign-accented speech. Language Learning, Michigan, v. 48, n. 2, p. 159-182, 1998.

PASSARELLA DOS REIS, L. What do you mean? Nuclear stress in English as an international language: Uses and interpretations. 2017. 327 f. Tese (Doutorado em Letras Inglês) - Centro de Comunicação e Expressão, Universidade Federal de Sana Catarina, Florianópolis, 2017.

PEREIRA, A. L. D. Caracterização acústica do sistema vocálico tônico oral florianopolitano: alguns indícios de mudança. 2001. 108 f. Dissertação (Mestrado em Linguística) - Centro de Comunicação e Expressão, Universidade Federal de Santa Catarina, Florianópolis. 2001.

RATO, A. Cross-language perception and production of English vowels by Portuguese learners: the effects of perceptual training. 2013. 375p. Dissertation (Ph.D. inLanguage Sciences) - University of Minho, Instituto de Letras e Ciências Humanas, Minho, 2013.

RAUBER, A. S. Perception and production of English vowels by Brazilian EFL speakers. 2006. 218 f. Tese (Doutorado em Letras Inglês) - Centro de Comunicação e Expressão, Universidade Federal de Santa Catarina, Florianópolis. 2006.

ROACH, P. English Phonetics and Phonology: A practical course. 3. ed. Cambridge: Cambridge University Press, 2000. 298 p.

SAITO, K.; WU, X. Communicative focus on form and second language suprasegmental learning: Teaching Cantonese learners to perceive Mandarin 
tones. Studies in Second Language Acquisition, Cambridge, v. 36, n. 4, p. 647680, Sept. 2014.

SEARA, I. C. Estudo acústico-perceptual da nasalidade das vogais do português brasileiro. 2000. 291 f. Tese (Doutorado em Linguística) - Centro de Comunicação e Expressão, Universidade Federal de Santa Catarina, Florianópolis. 2000. TROFIMOVICH, P.; BAKER, W. 2006. Learning second language suprasegmentals: effect of L2 experience on prosody and fluency characteristics of L2 speech. Studies in Second Language Acquisition, Cambridge, v. 28, n.1, p. 1-30.

WATKINS, M. A. Variability in vowel reduction by Brazilian speakers of English. 2001. 248 f. Tese (Doutorado em Letras Inglês) - Centro de Comunicação e Expressão, Universidade Federal de Santa Catarina, Florianópolis. 2001.

; RAUBER, A. S. Variability in pretonic vowel reduction by Brazilian speakers of English. In: RAUBER, A. S. et al. The Acquisition of a second language speech: studies in honor of professor Barbara O. Baptista. Florianópolis: Insular, 2010. p. 75-100.

WATKINS, M. A.; ALBINI, A. B.; BERTOCHI, M. Suffering from stress patterns that give Brazilian a hard time. In: RAUBER, A. S. et al. The Acquisition of a second language speech: studies in honor of professor Barbara O. Baptista. Florianópolis: Insular, 2010. p. 305-318.

YAVAS, M. Applied English phonology. Oxford: Wiley-Blackwell, 2011. 319p. 


\section{APPENDIX}

\section{PRODUCTION TEST A - ENGLISH SENTENCES}

Everyone agrees that an apple a day keeps doctors away.

I travelled to South Africa, Congo and Uganda by myself.

That umbrella belongs to Jessica Park.

I think Canada is larger than the United States of America and Brazil.

There is a gorilla in the picture above.

Some people can't dance the samba.

The words 'but' and 'cut' sound like 'hut'.

I wish I could travel to Tampa - Florida one day.

I am taking yoga classes once a week.

The words 'love' and 'dove' sound like 'glove'.

In Canada, one can listen to many indigenous languages apart from English and French.

Some of the greatest loving songs were written by men.

Recebido em: 02/05/2017

Aceito em:18/07/2017 